\title{
Teaching the evaluation of web usability
}

\begin{abstract}
This paper describes the design and use of a simple method for comparative website evaluation that has been used for the purposes of teaching web design to University students. The method can be learnt within two hours by a novice user or typical customer. The method is not dependant upon the environment being used by the tester and can be adjusted according to the subjective preferences they may have. Results are presented of the use of the method in practice in comparing the sites of a number of airlines. These suggest that the method is both sufficiently rigorous to produce reliable results, and flexible enough for users to customise. It is an effective tool in teaching the principles of web design.
\end{abstract}

Keywords: Website evaluation, user evaluation, web metrics, usability

\section{Biography}

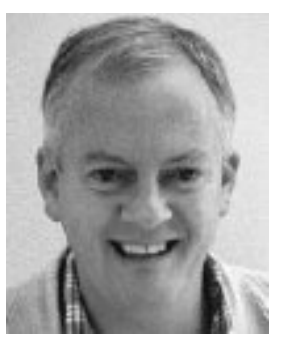

Chris Procter is a senior lecturer in the Information Systems Institute, University of Salford. His main teaching is in Project Management. He coordinates the work of Graduate Teaching Assistants in the ISI and is the Industrial Placement co-ordinator. He is also second year tutor for full time undergraduates. His research is primarily into teaching and learning and especially blended learning and he is a member of the Higher Education Research Centre.

He is responsible for a number of funded projects including a major European Social Fund project to provide 'Flexible IT' to people from the North West. He is a member of the British Computer Society and the Higher Education Academy. He has worked at Salford since 1991 with a one year gap in 1999-2000 based at the Open Polytechnic of New Zealand.

His main area of research interest and activity is in the area of Teaching and Learning. He has taken part in numerous workshops, seminars and conferences concerning this area over the last few years.

Material published as part of this publication, either on-line or in print, is copyrighted by the Informing Science Institute. Permission to make digital or paper copy of part or all of these works for personal or classroom use is granted without fee provided that the copies are not made or distributed for profit or commercial advantage AND that copies 1) bear this notice in full and 2) give the full citation on the first page. It is permissible to abstract these works so long as credit is given. To copy in all other cases or to republish or to post on a server or to redistribute to lists requires specific permission and payment of a fee. Contact Publisher@InformingScience.org to request redistribution permission. 